\title{
SIMULACIÓN DE LA PUESTA EN MARCHA DE UN REACTOR DE BIOPELÍCULA ANAEROBIA TIPO INTERCAMBIADOR DE CALOR
}

\section{Ramiro Escalera Vásquez}

\section{RESUMEN}

Se ha desarrollado un modelo de reactor que considera la separación de fases microbianas dentro de un reactor anaerobio tipo intercambiador de calor, donde las bacterias acidogénicas predominan en la masa líquida recirculante y las heteroacetogénicas y metanogénicas lo hacen en la biopelícula adherida a las paredes. El modelo considera también las resistencias difusionales a la transferencia de masa ocasionadas por la capa laminar y la biopelícula. También se consideran las reacciones paralelas y consecutivas propias de la degradación anaerobia de compuestos orgánicos fácilmente biodegradables, por ejemplo, residuos industriales de altas concentraciones de carbohidratos. El modelo de reactor y las ecuaciones pseudo-analíticas para la estimación de los factores de efectividad, desarrolladas para otro tipo de bioreactores anaerobios tales como lechos empacados y fluidizados, pueden utilizarse para estimar la eficacia y evaluar el funcionamiento de un Reactor de Biopelícula Anaerobia tipo Intercambiador de Calor (RBAIC) . En este trabajo se ha verificado que los resultados del modelo concuerdan con los resultados experimentales de la eficacia y funcionamiento del RBAIC, dentro del periodo de puesta en marcha.

Palabras Clave: Biopelículas Anaerobias, Intercambiador de Calor, Factores de Efectividad, Tratamiento de Aguas Residuales. 